\title{
Customer-Bank Relationship in Commercial Banks Operating in Albania
}

\author{
Jasmina Lumanaj, $\mathrm{PhD}$ (c) \\ Assistant Professor, Faculty of Economics \\ University of Shkodra "Luigi Gurakuqi" Shkoder, Albania \\ j_lumani@yahoo.com \\ Virtyt Lesha \\ Master of Science, Faculty of Information Technology \\ virtytl@hotmail.com
}

\begin{abstract}
Financial institutions with high performance are always looking to the needs and requirements of their clients, in order to survive and compete successfully in today's dynamic environment of corporations. For this reason researchers have stressed repeatedly the importance of customer satisfaction, loyalty and customer-bank relationship. The aim of this study is to develop a better theoretical and practical understanding of the impact that quality of service has in customer-bank relationship. This study examines the perception of service quality by clients of commercial banks operating in Albania and the effect that this quality has in customer-bank relationship. Measuring the perception of service quality is based on SERVQUAL model proposed by Parasuraman, Zeithaml \& Berry (1988), while the measurement of customer-bank relationship is made according to the model proposed by Ward \& Dagger (2007). Results of this analysis indicate that the quality of service is an important prerequisite of customer-bank relationship. From this study it is clear that managers and decision-makers in commercial banks in Albania seek to improve the quality of service elements, which constitute the most significant contribution to the improvement and strengthening of the relationship.
\end{abstract}

Keywords: service quality, customer-bank relationships, commercial banks, Albania

\section{Introduction}

Before the $90 \mathrm{~s}$, Albania had a planned economy of eastern nature. After this period, started the transformation process of this economy into Western market economy. Transformation from planned economy system to market economy system was necessary in the context of the reform of the Albanian economy affected by the profound political changes that took place in Albania in the early 90 s.

Noting that the financial system has a profound influence on other sectors of the economy, the more efficient and rapid the reform of this system is, the faster and easier it will accomplish the transformation process.

At the time of drafting measures to transform the country into a market economy was important to be taken into account the fact that in 45 years of communist rule, Albania has applied the most extreme policies of the state dominance in economy, politics related to centralized planning and property rights. In the years ' $85-90$ ' there were some limited reforms, but they had no positive effect, but further increased the economic difficulties, resulting in 1990 with the budget deficit that constituted $15 \%$ of the gross domestic product (GDP) for the period. Starting from this period, one after the other the crises continued and led to the destruction of the old regime. Thus started the transition to a market economy, but being in a hostile environment, the economy went into collapse; inflation rose at extraordinary rates and the external debt raised as well.

Albania's financial system incorporates the institutions, markets and financial instruments, but the transformation and reformation of this system was based mainly on reforming the financial institutions operating in the country, since financial markets and instruments were virtually nonexistent during the period of socialist economy. The financial system in Albania during the last 25 years has encountered various difficulties and faced many challenges to get where it is today. Banking 
institutions have already increased competition with each other through different ways and manners. They compete on how we provide products, the type of products, services provided, etc.

One of the most important recent trends is the Information Technology. The main advantage and the strongest point of development of the banking industry's voice seem to be the application of modern information technologies.

In today's market, where competition has become very intense, it is possible to obtain a quality service increasingly higher.

The increase of customer expectations and compliance has made essential the quality of service for an organization's success in many markets, (Parasuraman, Berry and Zeithaml 1991).

\section{Review of literature}

\section{Quality of Service}

Nowadays, with the continued increased competition, quality of service has become an important sector of academic study, being recognized as a key factor in maintaining competitive advantage and maintaining satisfactory relationships with customers (Zeithmal et al., 2000). Quality of banking service is widely recognized as a critical precondition for satisfying and retaining valuable customers (Taylor and Baker, 2004). Thus, service managers are aware that to successfully deploy the service quality as a competitive advantage, they must first identify exactly previous events and specifically what the customer perceives with the "quality" of service.

Gronroos (1982) describes the overall quality of service as the consumer's perception to distinguish between expected service and perceived service.

Parasuraman et al., (1985) defines quality of service as a comparison between the customer's expectations and perceptions of service. Furthermore, Parasuraman et al., (1988) provides the conceptual definition of service quality: "Perceived service quality is a global trial, or attitude related to the superiority of service, while satisfaction is related to a specific transaction."

If the service industry assesses the quality of service and development of the customer relationship, then success in these areas will be reflected in the increase of customer retention. Moreover, in a long-term perspective, these increases will be reflected in completely loyal clientele.

There are suggested three main points regarding quality:

1. Quality of services is more difficult to be estimated by the customer than the quality of goods;

2. Perceptions of the quality of service result from a comparison of customer expectations with the actual performance services; and

3. Assessments of quality are not only made in the result of service, they should include even the assessments of the progress of service delivery process.

Moreover, Parasuraman et al.., (1985) suggested "The model on the quality of service" in order to serve as a framework for further scientific research in this field. 


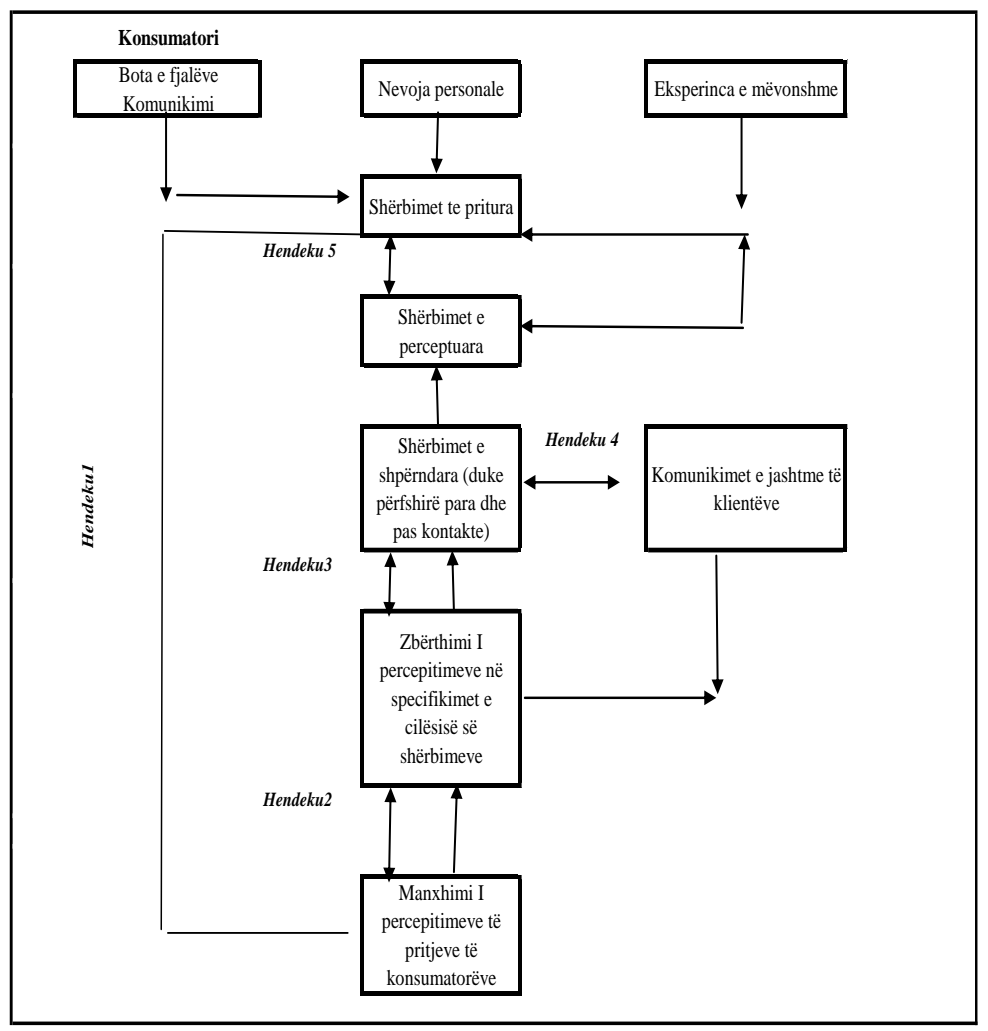

BuriBurimi: Parasuraman et al.,1985.

Services have four characteristics that distinguish them from the products produced. Services are: 1. Intangible 2. heterogeneous 3. corruptible 4. inseparable

These four characteristics show that service quality is a more elusive and abstract construct than the product quality (Parasuraman, et al, 1985). Based on this background, Gronroos (1984), defines quality as "the result of an evaluation process where the customer compares his expectations with the perceived service he receives, which means that he places the perceived service against the expected service."Based on the above, the quality of service can be conceived as the socalled "gap" between what customers feel that a service company should provide (this is their expectation) and their perception of the actual performance of service (Parasuraman et al, 1988). This concept was the basis for measuring the SERVQUAL scale, which was developed by Parasuraman et al and later improved by the same authors.

Parasuraman et al claimed that customers evaluate service quality by comparing their expectations and perceptions of the ten dimensions: reliability, responsiveness, competence, access, courtesy, communication, credibility, security, understanding and vulnerability. These dimensions were reduced later in 5 of them:

Vulnerability, Reliability, Responsibility, Safety, Empathy (Parasuraman, 1991, p. 422).

\subsection{Customer-bank relationship}


The attitude of the client in any form of relationship between the customer and the service provider is important, therefore as strong is the perception that the client has about the importance of the relationship in general, as likely it is for the client to develop a stronger relationship with the service provider (Ward et al., 1997).

There are several potential dimensions for this kind of relationship, meaningful dimensions, of bonding, empathy, reciprocity, trust, friendship, knowledge, thinking, understanding, time to listen, commitment, loyalty and common values. The importance of these dimensions to customers can affect the strength of relationship developed between the service provider and the customer.

One of the basic principles of marketing relationship is customer orientation. SOCO measurement method (selling orientation - customer orientation), developed by Saxe and Weitz (1982) is based on the premise that the customer-oriented vendors try to increase long-term satisfaction of the customer. Customer oriented retailers are considered as people who precede the achievement of an urgent sale at the expense of customer needs. Subsequent research has shown that the level of client orientation has an effect on a company's relationship with its customers (Clark, 1997; Yavas et al., 2004). Interaction between the customer and service provider is an important determinant of perceived service quality (Zeithaml et al., 1988). In some cases, this interaction can be largely transactional in nature, but more often the interaction occurs within the context of an ongoing relationship service.

Leverin and Liljander (2006, p. 234) argue that not all customers evaluate a relationship and close relationships with the bank are rare due to the increased use of self-use technologies.

According to Christopher et al (2002, p. 8), a customer service strategy is oriented towards keeping customers and building relationships.

\section{Marketing orientation relationship (Christopher et al, 2002, p. 9)}

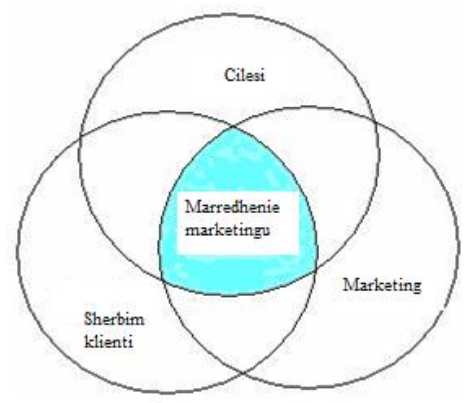

Ward and Dagger (2007) measured the impact of the importance of relations with customers, duration, frequency, age and gender, type of product and service to strengthen the relationship (p. 282). Results related to the bank showed that there is only a weak link between the length and strength of the relationship and not related to the frequency of use (p. 285) 


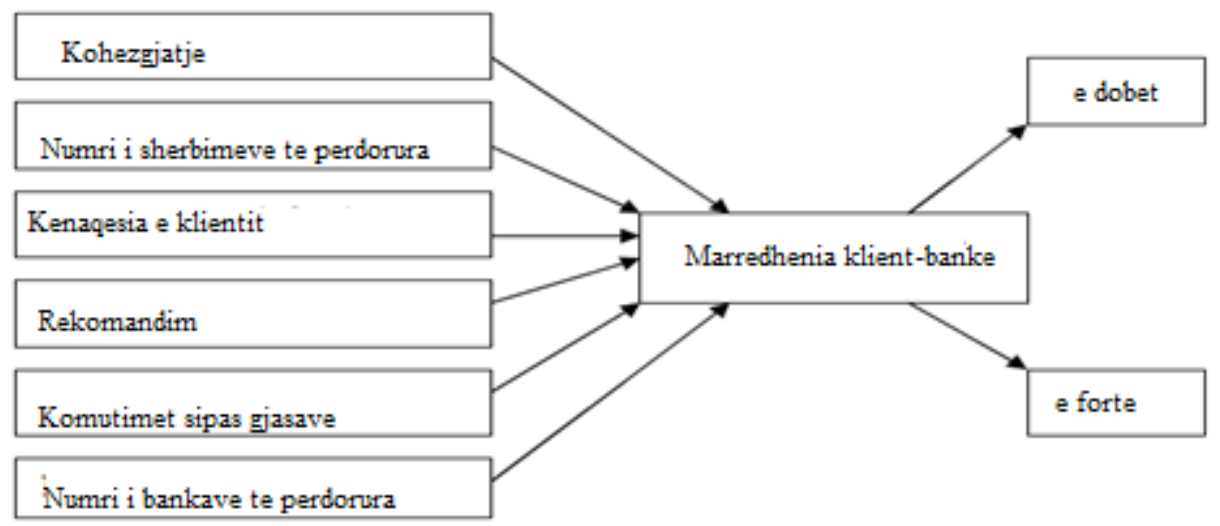

\section{Research question, hypothesis and paper methodology}

The main issues discussed in this research are service quality and customer-bank relationship using SERVQUAL model in the banking context. In this study I will answer the questions:

- How consumers perceive quality of service in the banking sector?

- Does a strong customer-bank relationship exist in Albanian commercial banks?

The aim of this study is to develop a better theoretical and practical understanding of the impact that quality of service has in customer-bank relationship.

This study tests the banking sector through SERVQUAL model by measuring the quality of service and customer-bank relationship.

Based on the findings made during the review of the literature, we believe that the quality of service is a precursor of a customer-bank relationship. Consequently the basic hypothesis is:

H1. Quality of service directly and positively influences customer-bank relationship.

The study was conducted in Shkodra, a city which has 13 different branches of commercial banks. The survey was based on web and the link was mailed to 200 customers of different banks, beneficiaries of various banking services (salary recipients, depositors, creditors, etc.). Only 160 people completed the survey, thus having a return reply order of $80 \%$. The questionnaire had three parts. The first part of the questionnaire serves to measure quality of service valued by customers. The second measures customer-bank relationship and the third the demographic variables.

\section{Measured variables}

\section{Independent variable - Quality of service.}

The measure is based on a modified version of the proposed SERVQUAL by Parasuraman et al. (1988), which consists of 22 elements, grouped into five dimensions of service quality, respectively Vulnerability (how modern the equipment bank, how attractive are the physical objects of the bank, as skillful employees of the bank, how attractive are materials related to the service), reliability (when the bank promises to do something at a certain time, she does it, when the customer has a problem bank shoes genuine interest for its solution, the bank is engaged in the right way at the Previously, the bank offers its services in a timely manner, the bank insists on the data without errors), Accountability (bank employees indicate exactly when the service is performed, the bank's employees provide rapid service, bank employees have always desire 
to help, bank employees are never so busy to respond to your requests), security (the behavior of bank employees instill confidence in customers, the bank you feel confident to perform transactions, bank employees are always kind to you, bank employees have the necessary knowledge to answer your questions), Empathy (bank offers individual attention, the bank working hours convenient for all customers, bank employees who give you personal attention, fond bank has your best interest, bank employees understand the specific needs of clients)

These elements are assessed with 7-point Likert scale, where $1=$ absolutely disagree and $7=$ strongly agree.

\section{Dependent variable - bank customer relationship}

Measurement of customer-bank relationship is based on the model proposed by Ward \& Dagger (2007). The model uses 8 evaluative questions of customer-bank relationship.

According to this model, to assess this relationship it is measured the impact of the importance of relations with customers, duration, frequency, age and gender, type of product of service to strengthen the relationship. Also it is measured the strength of the bank-customer relationship taking the perceived quality of customer service, as the basis for satisfaction. Finally, through an empirical study of customers of banks it is tested a model relationship. What we want to examine is mainly the strength or weakness of a customer-bank relationship, determined by the above factors.

\section{Analysis, data interpretation and conclusions}

\subsection{Demographic data of the respondents}

Table 2 presents the demographic data of respondents. As seen $40 \%$ of respondents were male, while $60 \%$ were female. The majority of respondents were highly educated. This category accounts for $53.4 \%$ of respondents, followed by respondents with university master, who make up $25.9 \%$ of respondents and $13.8 \%$ of the doctoral education of the respondents. The income level of $42.1 \%$ of the respondents is $40000-59999 \mathrm{ALL}$, followed by $17.5 \%$ of respondents to levels 60000-79999 and 80000-99999 ALL

\subsection{The evaluation of the quality of service}

To collect data about the perception of the quality of service that clients used a questionnaire, which contained 22 allegations suitable for measuring customer perceptions about the quality of service performance. Of these 22 claims, the first four belong dimension of vulnerability five belonging dimension of reliability, four belonging dimension of accountability, four belong to the security dimension and the last five belong dimension of empathy.

Table 3: Summary of descriptive statistics dimensions of service quality

\begin{tabular}{|l|l|l|l|l|l|}
\hline Dimensions & $\mathrm{N}$ & Minimum & Maximum & Average & Standard deviation \\
\hline General quality & 160 & 1.43 & 7.00 & 5.1016 & 1.13213 \\
\hline Vulnerability & 160 & 2.00 & 7.00 & 5.0333 & 1.15299 \\
\hline Reliability & 160 & 1.40 & 7.00 & 5.0017 & 1.34297 \\
\hline Accountability & 160 & 1.00 & 7.00 & 5.1597 & 1.46437 \\
\hline Security & 160 & 1.00 & 7.00 & 5.2972 & 1.28261 \\
\hline Empathy & 160 & 1.00 & 7.00 & 5.0158 & 1.19977 \\
\hline Valid N (listëise) & 160 & & & & \\
\hline
\end{tabular}

From the statistics summarized in Table 3 noted that the highest rating for the quality of service takes the fourth dimension, security. This dimension takes an average 5.29 rating, which shows that customers generally evaluate their safety and services they receive from banks. They feel safe and bank employees manage to instill confidence to these consumers. Instead, the second dimension of the low scores the average 5.0017. This means that customers do not appreciate sufficiently the possibility that employees of banks to solve their problems. To improve the assessment of this dimension 
employee must have special training for the recognition more and better banking products in general, for their behavior and willingness to convey their knowledge.

As seen in Table 4, the dimension of vulnerability more respondents judge the ability of employees, with average 5.1, followed by a 5.08 average estimate of physical objects attractive bank. In the dimension of reliability, respondents estimate mostly error-free performance of the bank considering a 27.5 average, followed by the provision of services in a timely manner with an average 5:05. In the dimension of accountability gets highest rating 5.4 Employee desire to help clients. Security dimension receives the highest rating 5.6 good employee behavior, but care must be taken with confidence that I transmitted to customers, since this statement gets the lowest score of the relevant dimension 5:08.

In the dimension of sensitivity receives highest rating 23.5 individual attention provides customer banks, and less with 4.75 estimated as the bank heartfelt best interest of the client.

\begin{tabular}{|c|c|c|c|c|}
\hline & Minimum & Maximum & Average & $\begin{array}{l}\text { Standard } \\
\text { deviation }\end{array}$ \\
\hline \multicolumn{5}{|l|}{ The dimension of Vulnerability } \\
\hline The bank XYZ has modern equipment & 1 & 7 & 5.07 & 1.425 \\
\hline Bank XYZ physical facilities have attractive appearance & 1 & 7 & 5.08 & 1.488 \\
\hline The XYZ bank's employees look quite capable & 1 & 7 & 5.1 & 1.515 \\
\hline $\begin{array}{l}\text { XYZ bank materials related to service (flyers, brochures, etc.) are } \\
\text { significantly more attractive }\end{array}$ & 1 & 7 & 4.88 & 1.627 \\
\hline \multicolumn{5}{|l|}{ The dimension of reliability } \\
\hline $\begin{array}{l}\text { When the bank XYZ promises to do something at a certain time, it makes } \\
\text { it }\end{array}$ & 1 & 7 & 4.8 & 1.571 \\
\hline $\begin{array}{l}\text { When you have a problem, Bank XYZ shows sincere concern for his } \\
\text { resolution }\end{array}$ & 1 & 7 & 4.88 & 1.658 \\
\hline XYZ bank performs adequately service for the first time & 1 & 7 & 5.03 & 1.551 \\
\hline The $X Y Z$ bank offers its services on a timely basis & 1 & 7 & 5.05 & 1.419 \\
\hline The $X Y Z$ bank insists on the data without errors & 1 & 7 & 5.27 & 1.706 \\
\hline \multicolumn{5}{|l|}{ The dimension of accountability } \\
\hline XYZ bank's employees tell you exactly when the service will be performed & 1 & 7 & 5.17 & 1.743 \\
\hline XYZ bank's employees provide you fast service & 1 & 7 & 5.27 & 1.518 \\
\hline XYZ bank's employees have always desire to help & 1 & 7 & 5.4 & 1.509 \\
\hline $\mathrm{XYZ}$ bank's employees are never so busy to respond to your requests & 1 & 7 & 4.88 & 1.609 \\
\hline \multicolumn{5}{|l|}{ The dimension of the security } \\
\hline $\begin{array}{l}\text { The behavior of the employees of XYZ Bank instills confidence in } \\
\text { customers }\end{array}$ & 1 & 7 & 5.08 & 1.629 \\
\hline Bank $X Y Z$ you feel secure for transactions that you do & 1 & 7 & 5.39 & 1.509 \\
\hline XYZ Bank employees are continuously polite with you. & 1 & 7 & 5.6 & 1.543 \\
\hline
\end{tabular}




\begin{tabular}{|l|l|l|l|l|} 
XYZ Bank employees have the required knowledge to answer your & & & \\
questions & 1 & 7 & 5.12 & 1.508 \\
\hline The empathy dimension & & & & \\
\hline XYZ Bank offers individual attention & 1 & 7 & 5.23 & 1.466 \\
\hline XYZ Bank has adequate working hours for all customers & 1 & 7 & 5.15 & 1.818 \\
\hline XYZ Bank has employees who give you personal attention & 1 & 7 & 5 & 1.629 \\
\hline XYZ Bank has cordial your best interest & 1 & 7 & 4.75 & 1.503 \\
\hline XYZ Bank employees understand your specific needs & 1 & 7 & 4.95 & 1.489 \\
\hline
\end{tabular}

Table 2: Demographic data

\begin{tabular}{|l|l|}
\hline Level of income (ALL) & Percentage \\
\hline Less than 10.000 & 3.5 \\
\hline $10-000-19.999$ & 1.8 \\
\hline $20.000-39.999$ & 15.8 \\
\hline $40.000-59.999$ & 42.1 \\
\hline $60.000-79.999$ & 17.5 \\
\hline $80.000-99.999$ & 17.5 \\
\hline More than 100.000 & 1.8 \\
\hline Total & 100 \\
\hline Education & \\
\hline High school & 6.9 \\
\hline University & 53.4 \\
\hline Master & 25.9 \\
\hline PhD & 13.8 \\
\hline Total & 100 \\
\hline Gender & \\
\hline Male & 40 \\
\hline Female & 60 \\
\hline Total & 100 \\
\hline
\end{tabular}

\subsection{Evaluation of relationship customer-bank}

The table below gives the results of the questionnaire related to customer-bank relationship. 


\begin{tabular}{|l|l|}
\hline Duration as a customer in bank XYZ & Percentage \\
\hline Less than a year & 13 \\
\hline $1-2$ years & 23 \\
\hline $2-3$ years & 18 \\
\hline $3-4$ years & 15 \\
\hline $4-5$ years & 11 \\
\hline 5 years & 19 \\
\hline Total & 100 \\
\hline Do you think you will continue in this bank? & \\
\hline Yes & 83 \\
\hline No & 17 \\
\hline Total & 100 \\
\hline Do you use more banks than this one? & \\
\hline Yes, 1 & 27 \\
\hline Yes, 2 & 33 \\
\hline Yes, 3 & 12 \\
\hline Yes, 4 & 2 \\
\hline Yes, more than 4 & 2 \\
\hline No & 25 \\
\hline Total & 100 \\
\hline How often do you use internet banking? & \\
\hline Several times a week & 24 \\
\hline Once a month & 49 \\
\hline Once a week & 20 \\
\hline More often & 7 \\
\hline Total & 100 \\
\hline & \\
\hline & \\
\hline & \\
\hline & \\
\hline
\end{tabular}

\subsection{Dependence between service quality and customer-bank relationship}

Linear regression analysis where the independent variable is the quality of service and the dependent variable customerbank relationship shows that R2 is $0: 45$, which shows that $45.0 \%$ of changes in customer-bank relationship are explained by the perception of service quality.

Therefore, the $\mathrm{R} 2$ value is not the result of chance; independent variables are able to explain the variation in the dependent variable. The relationship between the independent and dependent variable is given by the following equation:

Customer-bank relationship $=0.083+0.236$ (quality of service)

The regression coefficient is positive and shows a positive correlation between the independent and dependent variable. It means that by increasing the level of perceived quality of services we would have increased the bank customer relationship, so we will have strong relationships.

The figure below shows the graphic output in multiple tests the relationship quality - customer -bank. The circle shows the calculated average and the line is the confidence interval of $95 \%$ for the calculated average. 


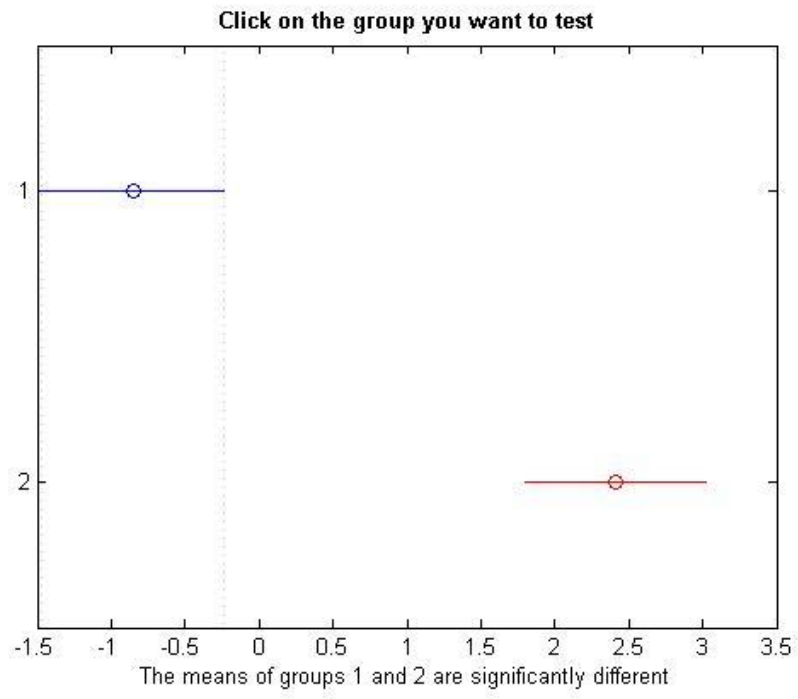

\section{References}

1. Clark, M. (1997). Modeling the impact of customer-employee relationship on customer retention rates in a major UK retail bank (3rd ed., Vol. 35, pp. 293-302). Management Decision.

2. Grönroos, C. (1992). Service Management and Marketing: Managing the Moments of Truth in Service Competition. Lexington Books.

3. Grönroos, C. (1994). From Marketing Mix to Relationship Marketing: Towards a Paradigm Shift in Marketing (2nd ed., Vol. 32, pp. 4-20). Management Decision.

4. Parasuraman, A., Zeithaml, V., \& Berry, L. (1988). SERVQUAL: A multiple-utem scale for measuring consumer perceptions of service quality (1st ed., Vol. 64, pp. 12-40). Journal of Retailing.

5. Parasuraman, A., Zeithaml, V., \& Berry, L. (1988). SERVQUAL: A multiple-item scale for measuring consumer perceptions of service quality (1st ed., Vol. 64, p. $12-40)$. Journal of Retailing.

6. Parasuraman, A., Zeithaml, V., \& Berry, L. (1994). Reassessment of expectations as a comparison standard in measuring service quality: Implications for further research. Journal of Marketing.

7. Ward, T., \& Dagger, T. (2007). The Complexity of Relationship Marketing for Service Customers (4th ed., Vol. 21, p. $90=281)$. Journal of Services Marketing.

8. Ward, T., Frew, E., \& Caldow, D. (1997). An extended list of the dimensions of 'relationship' in consumer service product marketing: A pilot study (Vol. 6, pp. 44-531). American Marketing Association.

9. Zeithaml, V., Bitner, M., \& Gremler, D. (2006). Services Marketing: Integrating Customer Focus Across the Firm, (4th ed.). McGraw-Hill International Edition

10. Ward, T., \& Dagger, T. (2007). The Complexity of Relationship Marketing for Service Customers (4th ed., Vol. 21, p. $90=281$ ). Journal of Services Marketing.

11. Leverin, A., \& Liljander, V. (2006). Does Relationship Marketing Improve Customer Relationship Satisfaction and Loyalty?, (4th ed., Vol. 24, pp. 51-232). International Journal of Bank Marketing.

12. Christopher, M., Payne, A., \& Ballantyne, D. (n.d.). Relationship Marketing: Creating Stakeholder Value, Butterworth-Heinemann. 